\title{
Knowledge spillovers and subsequent innovation in green energy: the role of public $R \& D$
}

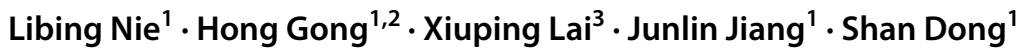

Received: 22 July 2021 / Accepted: 21 October 2021 / Published online: 2 November 2021

(c) The Author(s), under exclusive licence to Springer-Verlag GmbH Germany, part of Springer Nature 2021

\section{Introduction}

Knowledge spillover of technology innovation in green energy is pivotal for advancing subsequent innovation. To cope with climate change and air pollution, China is actively putting in place a comprehensive energy policy, including the restrictions on exploitation and utilization of fossil energy and the support to the development of green energy (Feng et al. 2020). In this process, technological breakthroughs in green energy are key factors in reducing the cost, while resource mobilization is an important constraint on energy transition (Zhao et al. 2019). Externalities existed in green energy technology, such as knowledge spillovers and short-term income uncertainty, cause insufficient motivation of private sectors for investing (Jaffe et al. 2005; Mowery et al. 2010), while public R\&D becomes an effective way to compensate for market failures and promote the development of new technologies (Aldieri et al. 2020). The term "public R\&D" refers to the various types of research institutions established and funded by the government, including universities, public research centers, and governmental organizations. The primary characteristic is that they are financed by the state and regulated by governmental policies. However, there are still questions about how to foster the leading role of public R\&D (Audretsch and Link 2019). Many states have confirmed that their own public funds for low-carbon energy technology have been

Responsible Editor: Philippe Garrigues

Hong Gong

00008960@whu.edu.cn

1 Economics and Management School, Wuhan University, Wuhan 430072, China

2 Research Center of Strategic Emerging Industries, Wuhan University, Wuhan 430072, China

3 School of Business, Nanjing University, Nanjing 210093, China increasing significantly ${ }^{1}$. The augment in public funds has a positive effect on green patent applications, but not on quality (Plank and Doblinger 2018). Public funds are definitely limited. Rather than adopting indiscriminate stimulus policies that would have an entire-technology-wide impact, targeted support, which is based on the characteristics of green energy technology development and the effects of capital investment, may generate agreeable changes of the efficiency and effectiveness of public resources (Plank and Doblinger 2018).

Targeted support requires to answer the question which green energy technology field deserves the most policy support. This question can be more explicit: What kind of roles does public R\&D play in different fields of green energy technology? Which fields generate higher social value? Furthermore, has the development of green energy technologies improved the technical level of the entire industry and enriched the technological development track of subsequent innovation? To answer these questions, a more detailed examination of knowledge spillovers among green energy technologies should be carried out. Analyzing the flow of knowledge, decision-makers can identify the most valuable investment in green energy and invest in the most likely successful technologies and institutions, which offer support to the construction of an energy innovation system (Chan and Daim 2012, 2018). Investigation of knowledge spillover paths of public R\&D in the field of green energy technology would contribute to answering the question that how each field of green energy technology interacts with each other.

This paper attempts to provide a comprehensive and objective evaluation of green energy innovations from public R\&D, as well as a marginal contribution to how public R\&D can impact subsequent innovation. First, we take a sample of green energy patents filed by public R\&D to analyze, quantitatively and qualitatively, the innovations obtained in different fields and the differentiated social values that they contribute. Second, the perspective and content of this paper

$\overline{1}$ http://mission-innovation.net/ 
are novel, as we further depict the directions of information flow in public $R \& D$ and analyze how public $R \& D$ acts on subsequent innovations. While enriching and expanding the theory of knowledge spillover, this paper will also contribute to a more elaborate development of green energy innovation.

The rest of this research is organized as follows. The "Literature review and questions" section presents the theory and hypotheses. The "Data and methods" section gives a brief description of the methodological approach, while the "Results" section shows the empirical results. The last section provides discussions and draws implications, limitations, and future research directions.

\section{Literature review and questions}

\section{Knowledge spillovers and social values}

Knowledge spillover, a major inseparable proposition of endogenous growth theory (Grossman and Helpman 1991), is the focus research issue in innovation. The substance of knowledge spillover refers to the process that principal owners have direct or indirect interaction with other parts, when knowledge dissemination or absorption may occur designedly and sometimes or incidentally (Caniels and Verspagen 2001). The brainchild and discoveries of inventors will inevitably spill over to other fields or departments, generating a positive externality to economic growth (Rennings and Rammer 2011). A main stream of associated researches, referring to the patent documentations and patent citation network analysis, makes efforts to outline a clear map for the exchange and cooperation among multi-inventors and to identify technology spillover paths (Koch and Simmler 2020; Messeni Petruzzelli and Murgia 2020). As found in some studies, the considerable privileged possession of forward-cited patents (highly cited patents) will play a key role and provide technical support for subsequent innovations (Schoenmakers and Duysters 2010). Therefore, a variety of literatures use patent citations to measure patents' quality (Jaffe and de Rassenfosse 2017) and propose that those cited more frequently have higher social value (Lanjouw and Schankeman 2004).

In recent years, the evolution of energy literatures shows a shift in more attention toward the knowledge spillover in the field of green energy (Popp 2019). It is examined that green technology has higher citation rates than non-green technology (Barbieri et al. 2020; Popp and Newell 2012). Researches in four technological fields, including energy production, transportation, fuel, and lighting, show an average disparity of $43 \%$ between knowledge spillovers of clean technology and traditional technology (Dechezleprêtre et al. 2014). Besides, studies have found that R\&D activities targeting clean technology may obtain higher returns than others (Colombelli and Quatraro 2019), and the benefits of positive externalities from high knowledge spillovers of clean technology may exceed the cost of environmental regulation (Marin 2014). At the same time, green technology tends to be more novel and complex, which can be used for multiple goals in multiple fields, as well as to generate more extensively spillovers and stimulation on subsequent innovations (Ghisetti et al. 2015; Florida 1996; Oltra and Jean 2005; Ardito et al. 2016; Pearson and Foxon 2012). However, a notable concern on the comparison between clean technology and traditional technology can be macro and nonintegrative. Considering the different importance and spillovers of multiple technological fields inside green energy opens up interesting theoretical and microcombination. Hence, our first concern is that which green energy technology will have larger effects on public institutions. One of the prerequisites of this issue is that different technologies have different inherent attributes, and certain technologies will obtain higher knowledge spillovers, that is, have greater social values.

Question 1: In which green energy technological fields do public R\&D perform better, and which fields have greater social values?

\section{Knowledge spillovers and subsequent innovation}

For the sake of transmission mechanism of technology innovation, it might behoove us to paint a rudimentary description of the direction of knowledge flow in addition to the magnitude (Nemet 2012; Colombelli and Quatraro 2019). For instance, where does the contribution of knowledge toward technological development come from? Resource dependence and technology evolution research have each considered knowledge accumulation but on separate tracks. Resource dependence theory (RDT) advocates that prior knowledge in specific domains can contribute to greater knowledge spillovers (Pfeffer 1972; Hillman and Dalziel 2003), because local knowledge search and learning on specific technology are conducive to the accumulation of knowledge (Dosi 1982; Cohen and Levinthal 1990). When new ideas and existing knowledge are combined with each other, new knowledge might be generated considerably (Schilling and Green 2011). From the perspective of technology proximity, patents with closer distances are more likely to make knowledge spillover effects (Nemet and Johnson 2012; Kaplan and Vakili 2015), while integration with longer distances may not only bring higher costs and more uncertainty (Todo et al. 2016; Kaplan and Vakili 2015), but may have a negative impact on the internal knowledge generation (Gkypali et al. 2017).

Separately, technology evolution theory claims that excessive emphasis on prior knowledge would lead to the technology similarity and incremental evolution, which may 
create a potential impediment of lock-in or path dependence (Burmaoglu et al. 2019). Obstacle avoidance, knowledge with highly heterogeneity but complementarity from dissimilar fields is worth of special values in promoting technology (Costantini et al. 2015). Meritorious inventions often come from knowledge systems that are interdepartmental but interconnected (Schilling and Green 2011). And subsequent innovations are profoundly affected by diverse knowledge and technology of various fields (Battke et al. 2016). As a result, the diversity of technology and knowledge can help promote valuable researches (Schoenmakers and Duysters, 2010) and radical innovations (van den Bergh 2008).

Compared with traditional energy technology, green energy technology tend to overflow into a wider range of fields and domains (Dechezleprêtre et al. 2014).However, existing research has not found out which green energy field can gain more benefits from specific technology. Knowledge production functions are applied to identify knowledge spillovers for specific energy technologies: intra-technology spillovers, inter-technology spillovers, or external spillovers (Griliches 1979). When shifting closer attention toward different fields, Dechezleprêtre et al. (2014) found a noteworthy phenomenon of inter-technology spillovers. Accumulation of prior knowledge inside the technology field has positive implications for subsequent innovations in energy (Ben Arfi et al. 2018), especially for wind energy and solar energy, both of which shows distinct innovation characteristics in intra-sectoral spillovers (Braun et al. 2010). The knowledge spillovers of green energy can come from fossil energy, too (Noailly and Smeets 2015).

There are also studies that employ patent citations for networking knowledge proliferation to provide evidence of the flow direction of knowledge spillover from green energy, but the development and overflow of disparate technological fields depend on its own inherent characteristics. Research on the network in the field of battery technology, as a typical example, has discovered that the centrality and diversity of existing technology influence its overflow direction and subsequent development (Battke et al. 2016). Knowledge with the scientific nature of expertise and centralization more likely to flow into the same field (Stephan et al. 2019), while knowledge of diversification and decentralization is inclined to flow to other fields (Barbieri et al. 2020). Therefore, we posit that, due to the inherent attributes of different technologies, green energy knowledge of different technological fields is somehow distinguished at the spillover directions. And then we propose another question:

Question 2: Which fields do green energy technology of public R\&D flow to? What is the impact on subsequent innovation?

\section{Data and methods}

\section{Data sources}

Our data collections involved four steps. We first gained the IPC codes and patent classification standards for alternative energy production from the IPC Green Inventory ${ }^{2}$ that were developed by the IPC Committee of Experts and then divided the green energy technology into eight technological fields. Second, we searched patents applied by Chinese public R\&D between 1985 and 2019 from the China National Intellectual Property Administration ${ }^{3}$ and PatSnap, ${ }^{4}$ a Chinese patent data service platform, and downloaded those met the requirements. After deleting data with missing values, 132,611 pieces of target patent data were finally left. Third, we identified the publication number listed in the forward citations and once again downloaded associated patents from the platform. Finally, the technological fields of both target patents and citations were attributed by comparing the IPC code of each with the standard. We match the citations' classification results with the target patents' classifications, so as to get access to the knowledge spillovers of public R\&D on green energy technology. The processes of match mentioned above were done in Python.

\section{Variables}

\section{Dependent variable}

Knowledge spillover (KS), the number of forward citations of target patents, is one of the most common indicators of patent influence. The more knowledge spillovers, the more target patents are cited and the greater their social values. Since we cannot contain all patents granted in the future, and there are differences in patent disclosure and duration, it is impossible to exhaust all the forward-cited data of target patents. Early patents often have more citation opportunities due to their longer duration, while the latest patents are often underestimated. In order to minimize this problem and enhance comparability, so that each patent has the similar weight (Nemet and Johnson 2012), we used citations within 5 years (Cited5) after publications.

Types of knowledge spillovers (type) By measuring the technological fields of the target patents and its forward citations, we could explore the directions of knowledge spillovers. On the basis of comparing the consistency of the technological fields and cited patents and citations, we use four terms to

\footnotetext{
${ }^{2}$ https://www.wipo.int/classifications/ipc/en/green_inventory/

3 http://www.cnipa.gov.cn/

${ }^{4}$ https://www.zhihuiya.com/
} 
capture types of knowledge spillovers: (a) intra-technology spillovers (Intra) that the target patents and forward citations are part of the same green energy technological field; (b) inter-green energy technology spillovers (inter-GET) that both patents and citations are attributed to green energy but not to the same sub-field and (c) inter-fossil fuel technology spillovers (inter-FF) that citations belong to traditional fossil fuel; and (d) external technology spillovers (External) that citations pertain to neither green energy nor traditional fossil energy but other non-energy technological fields like transportation, water, and chemistry.

\section{Independent variables}

We made the technological fields of green energy patents (Field) our independent variable. According to the $I P C$ Green Inventory and International Energy Agency ${ }^{5}$, the technological fields of green energy patents available can be defined as solar energy, wind energy, ocean energy, biofuels, geothermal energy, hydro energy, waste to energy, and others.

\section{Control variables}

Several control variables were included to improve the validity and reliability of our empirical analysis. Backward citations (BackCite) are supposed to reflect a patent's quality, as a patent referencing to more patent has more theoretical basis (Roach and Cohen 2013; Chen et al. 2016). On the other hand, more backward citations also indicate less innovative, with a smaller scope of protection and fewer citations. And the same thing goes for the citations of non-patent literatures (Non-patentCite) (Narin et al. 1997). Existing literatures have shown that there are some relationships between non-patent backward citations and patent forward citation. Besides, we controlled for the number of IPC codes (IPC), inventors (Inventor), applicants (Applicant), patent claims (Claim), and extended patent families (ExtendedFamily) (Markus and Reitzig 2004; Singh 2008; Novelli 2015).

\section{Empirical approach}

Poisson regression and zero-inflated negative binomial regression are the common models for count data (with a certain amount of zero outcomes) such as patent data (Drivas and Economidou 2015). Our samples, patents for green energy over the 1985-2019 period, are registered by Chinese public research and development institutions. During the sampling period, there are many zero values in our dependent variables of knowledge spillovers and types of knowledge spillovers. Poisson regression, whose expectation and variance must be equal, so called equidispersion (Hardin and Hilbe 2014), is a regression model for analyzing the dependent variable of non-negative integer count data like ours (Plank and Doblinger 2018). However, in our data, there is a statistical overdispersion problem that the variances of KS and Type are far more than their means. During our examination, the LR test of alpha $=0$ is rejected, and the statistics of Vuong (Vuong 1989) are small and less than zero; thus, a standard negative binomial regression model is used to fit the given set of empirical observations (Xu et al. 2010; Hardin and Hilbe 2014).

\section{Results}

In this section we paint a description of statistical data and regression results. The "Descriptive statistics" section contains a descriptive statistical analysis on all target patents. The "Distribution and social value" section first shows the time trend and distribution of green energy technology of public R\&D. It proceeds with estimation of patents' forward citations in different fields to compare and analyze the differences in the social value of different technical fields. The "Directions of knowledge spillovers" section further provides details of where does the green energy technology of public R\&D is flowing.

\section{Descriptive statistics}

Table 1 reflects some interesting characteristics of green energy innovation in public R\&D. Firstly, the median of application time is 2015, indicating that after 2015, public $R \& D$ has developed rapidly in the field of green energy technology. The mean size of inventors and applicants are 4.764 and 1.128, respectively, showing that green energy, as a new research field, is mostly the result of cooperation of multiple entities.

Secondly, in the forward citation index of patents, whether it is Cited3 or Cited5, the median is 0. More than half of the patents have never been cited since published. Many patents are in a dormant state, while the mean value is greater than 1 , which shows serious imbalance of the quality of green energy technologies in public R\&D We can also draw this conclusion from the extreme values of forward citations (the maximum value is 285 and the minimum value is 0 ).

Thirdly, the means of Intra, Inter-GET, Inter-FF, and External are 0.484, 2.047, 0.199, and 1.024, respectively, with the medians of Inter-GET and External being greater than 1 , which means that the green energy knowledge of

\footnotetext{
5 http://wds.iea.org/
} 
Table 1 Descriptive statistics

\begin{tabular}{|c|c|c|c|c|c|c|c|}
\hline Variables & Explanation & Obs & Mean & P50 & $\mathrm{Sd}$ & Min & $\operatorname{Max}$ \\
\hline ApplyYear & The year when a patent was applied & 132,611 & 2014 & 2015 & 4.602 & 1985 & 2020 \\
\hline Cited5 & Times of forward citations in 5 years & 132,611 & 1.577 & 0 & 3.767 & 0 & 285 \\
\hline Cited3 & Times of forward citations in 3 years & 132,611 & 1.162 & 0 & 2.844 & 0 & 285 \\
\hline Field & Technological fields of green energy that a patent belongs to & 132,611 & 3.875 & 4 & 2.64 & 1 & 8 \\
\hline Intra & Times cited by patents of the same green energy technological fields & 52,187 & 0.484 & 0 & 1.018 & 0 & 10 \\
\hline Inter-GET & Times cited by patents of other green energy technological fields & 52,187 & 2.047 & 1 & 2.536 & 0 & 29 \\
\hline Inter-FF & Times cited by patents of other fossil fuel technological fields & 52,705 & 0.199 & 0 & 0.717 & 0 & 9 \\
\hline External & Times cited by patents of non-energy technological fields & 52,705 & 1.024 & 1 & 1.306 & 0 & 11 \\
\hline IPC & The number of IPC code a patent owes & 132,611 & 3.442 & 3 & 2.323 & 1 & 96 \\
\hline Inventor & The size of inventors & 132,611 & 4.764 & 4 & 2.64 & 1 & 61 \\
\hline Applicant & The size of applicants & 132,611 & 1.128 & 1 & 0.427 & 1 & 13 \\
\hline Claim & The number of claims & 132,611 & 6.749 & 6 & 5.16 & 1 & 99 \\
\hline BackCite & Times of backward citation & 132,611 & 2.726 & 2 & 3.328 & 0 & 146 \\
\hline Non-patentCite & The backward citation times of non-patent literatures & 132,611 & 0.352 & 0 & 0.926 & 0 & 20 \\
\hline ExtendedFamily & The number of extended patent families & 132,611 & 2.036 & 1 & 6.291 & 0 & 796 \\
\hline
\end{tabular}

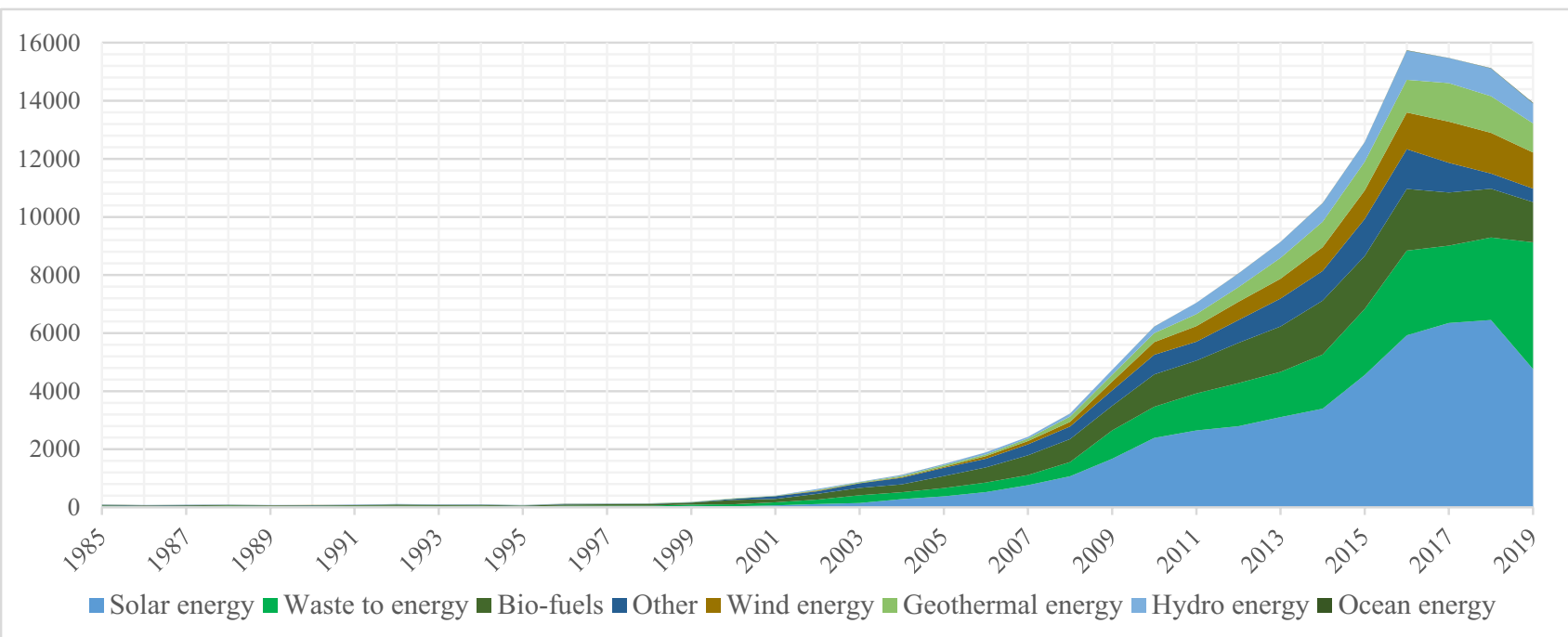

Fig. 1 Time trend of green energy technology in public R\&D institutions

public R\&D flows mainly into the fields of green energy, followed by the fields other than energy. It demonstrates that the investment for green energy technology is undoubtedly beneficial to its own. What is more, it cannot be ignored that investment in a certain field may not exactly be beneficial to itself but more likely to promote other green energy technological fields or other fields except energy.

The significant discreteness of forward citations does not appear in technological fields and backward citations. There is no remarkable difference between mean values and median values, both of which are greater than 2 for times of backward citations. Most of them have made references to other patents but few to non-patent literatures.

\section{Distribution and social value}

In this section we are going to answer question 1, that is, which technological fields do public R\&D have better performance. We complete this task by analyzing performances of quantity and quality of public $R \& D$ in various green energy technological fields.

Figure 1 shows the distribution and time trends of patents in various green energy technological fields by public R\&D. On the whole, the number of green energy patent applications increases from 106 in 1985 to 13,928 in 2019, with an annual average increase rate of $14.2 \%$. The number of patents is relatively low before 2000 , but it has boosted 
Fig. 2 Distributions and average citations of green energy technological fields in public R\&D

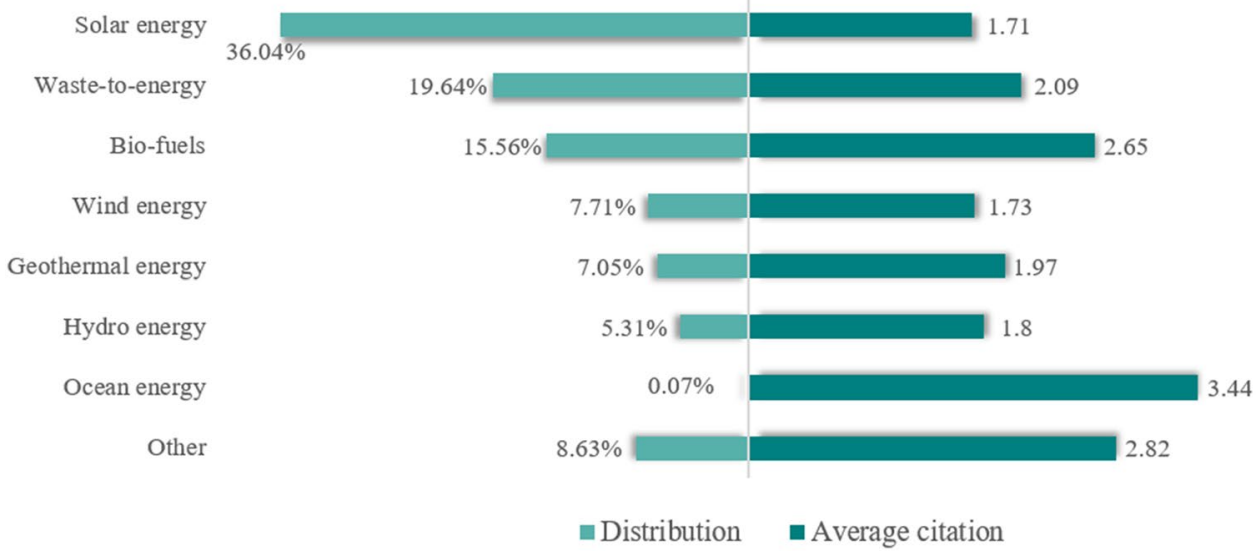

rapidly after 2007. This is because after the Kyoto Protocol, China have managed to take its common but differentiated responsibilities and shift to intensive sustainable development from economic growth with extensive features. Under the guidance of the conviction that lucid waters and lush mountains are invaluable assets, proposed by President $\mathrm{Xi}$ Jinping, China also pays high attention to the path of green and sustainable development. After 2016, turning points appear, and the growth rates of some fields show a downward trend, such as wind energy, geothermal energy, and hydro energy. At this moment, some solar and bio-fuels technologies have matured with a long period of technology accumulation; thus, public R\&D may be more likely to take effort to encourage commercialization. At the same time, with a series of strict ecological and environmental regulations put in place, waste to energy, represented by reutilization of surplus energy and incineration technology, has a greater rise rather than slightly decline.

Figure 2 shows the distributions and citations of green energy technologies of public R\&D in various fields. As shown in the left, most of the technologies pertain to the fields of solar energy, wind energy, and waste to energy (over $70 \%)$. Solar energy and wind energy are currently promising with few natural restrictions to growth, while the country's climbing efforts in pollution control have also promoted the exploitation and development of waste to energy. But in other fields, especially hydro energy and ocean energy, the technological foundation is quite weak. Although it is undoubtedly of great significance to the sufficiently development and utilization of China's marine resources and water resources, the research and development on pertinent technologies are at the starting stage, with high cost of equipment development and maintenance as well as insufficient R\&D motivation.

Comparing the left and right sides of the bar chart in Fig. 2 (where distribution represents quantity, and average citation represents quality), it can be easily found an imbalance in quantity and quality of different technologies fields in green energy. On average, regardless of the quantity, patents in all fields have been cited more than once. Among them, technologies in fields of ocean energy, bio-fuels, and other seem to have more likelihoods $(3.44,2.82$, and 2.65 respectively), which indicates that public $\mathrm{R} \& \mathrm{D}$ has more knowledge spillovers in these fields and makes a huger difference on subsequent innovation. In contrast, patents in other fields, such as solar energy and waste to energy, are superior in numbers but senior in citations. Therefore, we advocate that while stimulating public R\&D to invest more in green energy technologies, technological quality should be taken as a prominent factor.

To better understand the simple data description above, we preliminarily suggest that there are significant differences between the performances of quantity and knowledge spillovers of patents that public R\&D applied in green energy. Empirical test should be taken to support our suggestion. In Table 2, we designate forward citations of solar energy patents, the most numerous one, the benchmark variable to examine the knowledge spillovers and which field has a greater impact on subsequent innovation. The estimation is based on target patents from 1985 to 2015, with patent citations covering the periods over 1985-2019. Model 1 contains all of the control variables, and models $2-8$ are the results of gradually adding into technological fields.

Table 2 shows that the ocean energy field is extremely exceptional in forward citations, with an average reference of $44.8 \%$ higher than that in the solar energy field; thus, R\&D in this field are considered to have the orientation of abundant social value for public institutions. This is partly caused by the limitation of ocean energy patents to the options of citations. At the same time, patents in the field of geothermal energy are quantitative and qualitative, with an average of $8.0 \%$ more than solar energy, indicating that public research and development have created plenty of high-quality technologies in geothermal energy. In contrast, patents belonging to waste to energy and bio-fuels, which perform well in quantity, and hydro energy, which perform 
Table 2 Forward citations of green energy patents in different fields

\begin{tabular}{|c|c|c|c|c|c|c|c|c|}
\hline & (1) & (2) & (3) & (4) & (5) & (6) & (7) & (8) \\
\hline BackCite & $\begin{array}{r}0.048^{* * * *} \\
(0.002)\end{array}$ & $\begin{array}{r}0.048^{* * * *} \\
(0.002)\end{array}$ & $\begin{array}{r}0.048^{* * * *} \\
(0.002)\end{array}$ & $\begin{array}{r}0.048^{* * * *} \\
(0.002)\end{array}$ & $\begin{array}{r}0.048^{* * * *} \\
\quad(0.002)\end{array}$ & $\begin{array}{r}0.048^{* * * *} \\
(0.002)\end{array}$ & $\begin{array}{r}0.049^{* * * *} \\
(0.002)\end{array}$ & $\begin{array}{r}0.049^{* * * *} \\
(0.002)\end{array}$ \\
\hline $\begin{array}{l}\text { Non-pat- } \\
\text { entCite }\end{array}$ & $\begin{array}{r}0.061^{* * * *} \\
(0.006)\end{array}$ & $\begin{array}{l}0.061^{* * *} \\
\quad(0.006)\end{array}$ & $\begin{array}{r}0.061^{* * * *} \\
(0.006)\end{array}$ & $\begin{array}{r}0.063^{* * * *} \\
(0.006)\end{array}$ & $\begin{array}{r}0.064^{* * * *} \\
(0.006)\end{array}$ & $\begin{array}{c}0.064^{* * * *} \\
(0.006)\end{array}$ & $\begin{array}{r}0.064^{* * * *} \\
(0.006)\end{array}$ & $\begin{array}{r}0.064^{* * * *} \\
(0.006)\end{array}$ \\
\hline IPC & $\begin{array}{r}0.032^{* * * *} \\
(0.004)\end{array}$ & $\begin{array}{r}0.032^{* * *} \\
(0.004)\end{array}$ & $\begin{array}{r}0.032^{* * * *} \\
(0.004)\end{array}$ & $\begin{array}{r}0.031^{* * *} \\
(0.004)\end{array}$ & $\begin{array}{r}0.032^{* * * *} \\
(0.004)\end{array}$ & $\begin{array}{r}0.031^{\text {*** }} \\
\quad(0.004)\end{array}$ & $\begin{array}{r}0.030^{* * * *} \\
(0.004)\end{array}$ & $\begin{array}{r}0.030^{* * * *} \\
(0.004)\end{array}$ \\
\hline Inventor & $\begin{array}{r}0.032^{* * * *} \\
(0.003)\end{array}$ & $\begin{array}{r}0.032^{* * * *} \\
(0.003)\end{array}$ & $\begin{array}{r}0.032^{* * * *} \\
(0.003)\end{array}$ & $\begin{array}{r}0.032^{* * * *} \\
(0.003)\end{array}$ & $\begin{array}{r}0.033^{* * * *} \\
(0.003)\end{array}$ & $\begin{array}{r}0.033^{* * * *} \\
(0.003)\end{array}$ & $\begin{array}{r}0.033^{* * *} \\
(0.003)\end{array}$ & $\begin{array}{r}0.033^{* * *} \\
(0.003)\end{array}$ \\
\hline Applicant & $\begin{array}{c}-0.061^{* * *} \\
(0.017)\end{array}$ & $\begin{array}{c}-0.061^{* * *} \\
(0.017)\end{array}$ & $\begin{array}{c}-0.061^{* * *} \\
(0.017)\end{array}$ & $\begin{array}{c}-0.057^{* * *} \\
(0.017)\end{array}$ & $\begin{array}{c}-0.058^{* * *} \\
(0.017)\end{array}$ & $\begin{array}{c}-0.059^{* * *} \\
(0.017)\end{array}$ & $\begin{array}{c}-0.057^{* * *} \\
(0.017)\end{array}$ & $\begin{array}{c}-0.057^{* * * *} \\
(0.017)\end{array}$ \\
\hline Claim & $\begin{array}{r}0.022^{* * * *} \\
(0.002)\end{array}$ & $\begin{array}{r}0.022^{* * * *} \\
(0.002)\end{array}$ & $\begin{array}{r}0.022^{* * * *} \\
(0.002)\end{array}$ & $\begin{array}{r}0.022^{* * * *} \\
(0.002)\end{array}$ & $\begin{array}{r}0.023^{* * * *} \\
(0.002)\end{array}$ & $\begin{array}{r}0.022^{* * * *} \\
(0.002)\end{array}$ & $\begin{array}{r}0.022^{* * * *} \\
(0.002)\end{array}$ & $\begin{array}{r}0.022^{* * * *} \\
(0.002)\end{array}$ \\
\hline $\begin{array}{l}\text { Exptended- } \\
\text { Family }\end{array}$ & $\begin{array}{c}-0.017^{\text {**** }} \\
(0.003)\end{array}$ & $\begin{array}{c}-0.017^{* * *} \\
(0.003)\end{array}$ & $\begin{array}{c}-0.017^{* * *} \\
(0.003)\end{array}$ & $\begin{array}{c}-0.016^{* * *} \\
(0.003)\end{array}$ & $\begin{array}{c}-0.016^{* * *} \\
(0.003)\end{array}$ & $\begin{array}{c}-0.016^{* * *} \\
(0.003)\end{array}$ & $\begin{array}{c}-0.016^{* * *} \\
(0.003)\end{array}$ & $\begin{array}{c}-0.016^{* * *} \\
(0.003)\end{array}$ \\
\hline Wind energy & & $\begin{array}{c}-0.005 \\
(0.027)\end{array}$ & $\begin{array}{c}-0.004 \\
(0.027)\end{array}$ & $\begin{array}{r}-0.018 \\
(0.027)\end{array}$ & $\begin{array}{c}-0.008 \\
(0.027)\end{array}$ & $\begin{array}{c}-0.012 \\
(0.027)\end{array}$ & $\begin{array}{c}-0.024 \\
(0.028)\end{array}$ & $\begin{array}{c}-0.028 \\
(0.029)\end{array}$ \\
\hline Ocean energy & & & $0.471^{*}(0.210)$ & $0.459^{*}(0.210)$ & $0.468^{*}(0.210)$ & $0.464^{*}(0.210)$ & $0.452^{*}(0.211)$ & $0.448^{*}(0.211)$ \\
\hline Bio-fuels & & & & $\begin{array}{c}-0.067^{* * *} \\
(0.019)\end{array}$ & $\begin{array}{c}-0.058^{* *} \\
(0.019)\end{array}$ & $\begin{array}{c}-0.062^{* *} \\
(0.019)\end{array}$ & $\begin{array}{c}-0.075^{* * *} \\
(0.020)\end{array}$ & $\begin{array}{c}-0.079^{* * *} \\
(0.021)\end{array}$ \\
\hline $\begin{array}{l}\text { Geothermal } \\
\text { energy }\end{array}$ & & & & & $\begin{array}{r}0.101^{* * * *} \\
(0.026)\end{array}$ & $\begin{array}{r}0.096^{* * * *} \\
(0.026)\end{array}$ & $\begin{array}{l}0.084^{* * *} \\
(0.026)\end{array}$ & $0.080^{* *}(0.027)$ \\
\hline Hydro energy & & & & & & $\begin{array}{c}-0.051 \\
(0.030)\end{array}$ & $\begin{array}{r}-0.064^{*} \\
(0.031)\end{array}$ & $\begin{array}{r}-0.068^{*} \\
(0.031)\end{array}$ \\
\hline $\begin{array}{c}\text { Waste-to- } \\
\text { energy }\end{array}$ & & & & & & & $\begin{array}{r}-0.041^{*} \\
(0.018)\end{array}$ & $\begin{array}{r}-0.046^{*} \\
(0.019)\end{array}$ \\
\hline Other & & & & & & & & $\begin{array}{c}-0.017 \\
(0.022)\end{array}$ \\
\hline Constant & $\begin{array}{r}0.616^{* * *} \\
(0.026)\end{array}$ & $\begin{array}{r}0.617^{* * *} \\
\quad(0.026)\end{array}$ & $\begin{array}{r}0.616^{* * *} \\
\quad(0.026)\end{array}$ & $\begin{array}{r}0.625^{* * *} \\
\quad(0.027)\end{array}$ & $\begin{array}{r}0.611^{\text {*** }} \\
\quad(0.027)\end{array}$ & $\begin{array}{r}0.618^{* * *} \\
\quad(0.027)\end{array}$ & $\begin{array}{r}0.629^{* * * *} \\
\quad(0.028)\end{array}$ & $\begin{array}{r}0.633^{* * *} \\
\quad(0.029)\end{array}$ \\
\hline /lnalpha & $\begin{array}{r}0.831^{* * * *} \\
(0.009)\end{array}$ & $\begin{array}{r}0.831^{* * * *} \\
(0.009)\end{array}$ & $\begin{array}{r}0.831^{* * * *} \\
(0.009)\end{array}$ & $\begin{array}{r}0.830^{* * * *} \\
(0.009)\end{array}$ & $\begin{array}{r}0.830^{* * * *} \\
(0.009)\end{array}$ & $\begin{array}{r}0.830^{* * * *} \\
(0.009)\end{array}$ & $\begin{array}{r}0.830^{* * * *} \\
(0.009)\end{array}$ & $\begin{array}{r}0.830^{* * * *} \\
(0.009)\end{array}$ \\
\hline$N$ & 59,744 & 59,744 & 59,744 & 59,744 & 59,744 & 59,744 & 59,744 & 59,744 \\
\hline
\end{tabular}

Standard errors in parentheses

$* p<0.05$

$* * p<0.01$

$* * * p<0.001$

Target patents from 1985 to 2015, patent citations from 1985 to 2019

not so good in size, are less cited but for different reasons. For waste to energy, commercialization gets more interest after sufficient accumulation in recent decades. Given the development of China's bio-fuels technology being in its infancy, there are still bottlenecks in core technologies like material pretreatment and conversion and equipment development. There is no evidence that patents in wind energy or other green energy have less or more citations than an average solar patent.

In general, public research and development have limited knowledge spillovers in fields such as solar energy, biofuels, and waste to energy, all of which are considerable in total amount (more than $70 \%$ overall). Supporting policies to these fields should emphasize the balance development between quantity and quality. It is noteworthy that, in the fields of ocean energy and geothermal energy whose combined shares are no more than $8 \%$, public R\&D has obtained much higher levels of knowledge spillovers. Therefore, in these fields, it is better to improve the volume and accumulation of technologies under the premise of quality assurance. As for hydro energy, both the accumulation and knowledge base are demanding.

\section{Directions of knowledge spillovers}

This section presents where does knowledge of different technological fields flow to. Figure 3 shows the distributions of spillover directions for each sub-field. We find a 
Fig. 3 Types of patents' knowledge spillovers in various technological fields

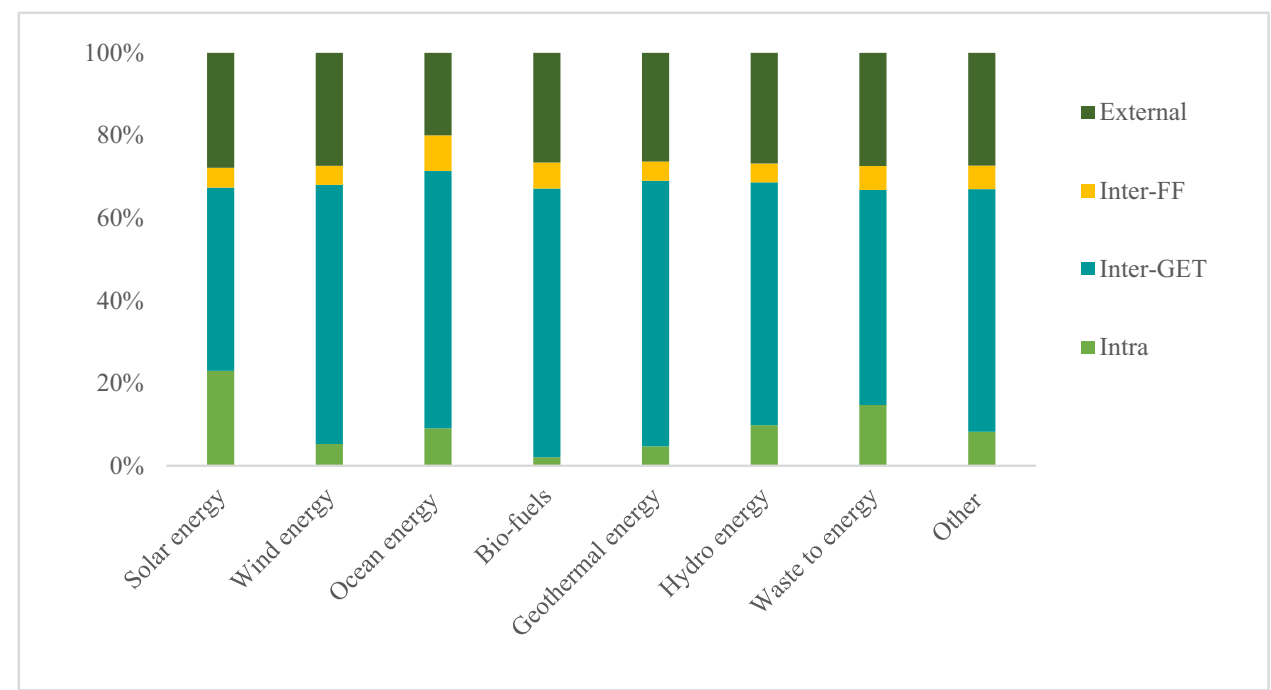

Table 3 Interflow among various technological fields

\begin{tabular}{lllllllllll}
\hline & Solar & Wind & Ocean & Bio-fuels & Geothermal & Hydro & Waste & Other & Fossil fuel & Non-energy \\
\hline Solar & 0.23 & 0.05 & 0.04 & 0.03 & 0.03 & 0.11 & 0.11 & 0.08 & 0.05 & 0.28 \\
Wind & 0.20 & 0.05 & 0.05 & 0.02 & 0.02 & 0.14 & 0.12 & 0.08 & 0.05 & 0.27 \\
Ocean & 0.20 & 0.02 & 0.09 & 0.01 & 0.01 & 0.17 & 0.15 & 0.05 & 0.09 & 0.20 \\
Bio-fuels & 0.20 & 0.03 & 0.10 & 0.02 & 0.02 & 0.12 & 0.16 & 0.07 & 0.06 & 0.21 \\
Geothermal & 0.19 & 0.07 & 0.05 & 0.04 & 0.05 & 0.09 & 0.15 & 0.06 & 0.05 & 0.26 \\
Hydro & 0.18 & 0.02 & 0.03 & 0.05 & 0.07 & 0.11 & 0.13 & 0.10 & 0.05 & 0.27 \\
Waste & 0.20 & 0.04 & 0.04 & 0.03 & 0.04 & 0.11 & 0.15 & 0.06 & 0.06 & 0.27 \\
Other & 0.21 & 0.05 & 0.05 & 0.02 & 0.03 & 0.09 & 0.14 & 0.08 & 0.05 & 0.27 \\
\hline
\end{tabular}

significant difference in the term of intra-technology spillovers (from 2 to $23 \%$ ). Prior knowledge in the fields of solar energy, hydro energy, and waste to energy makes greater contribution to their own. It shows that there is stronger path dependence in these fields and knowledge accumulation can provide impetus for subsequent innovation. When coming to wind energy, bio-fuel energy, and geothermal energy, intratechnology spillovers are relatively low, and their technological achievements are not enough to foster the development of themselves.

It is a remarkable fact that patents filed in public $R \& D$ tend to be referenced by other green energy fields (an average of 59\%). This demonstrates that the green energy research of public R\&D is internally widely used. Tight coupling among different technologies makes it feasible for technologies of any fields to provide consequential technical support for the development of green energy.

There are also technologies flowing into fossil fuel and non-energy technologies. The inter-fossil fuel technology spillovers are generally fewer (around 6\%), with ocean energy, waste to energy, and other green energy technologies being the slightly higher. Patents of these fields can provide more support for the development of fossil energy. The waste to energy technologies, as a common example, can be applied to the waste recycling of traditional fossil power generation. Besides, $26 \%$ of green energy technologies of public R\&D are cited by non-energy technologies in general, and the performance of each field is roughly at the same level.

In Fig. 3, we find that references of the green energy technologies developed by public R\&D mostly occur within the green energy field. Table 3 further shows the detailed distribution of knowledge spillovers for each field. Taking the first line as an example, we can see that $23 \%$ of solar energy technologies are cited by other solar energy technologies, $11 \%$ by hydro energy technologies, $11 \%$ by waste to energy technologies, and $28 \%$ by other green energy technologies.

A deeper look indicates that there are $20 \%, 17 \%$, and $15 \%$ of ocean energy technologies cited by solar, hydro, and waste to energy, respectively, suggesting that the technological development of ocean energy will have a greater enhancement on these fields. In addition, patents in solar, hydro, and waste to energy frequently reference to other green energy technologies. It can be considered that the development of 
Table 4 Regression results of knowledge spillover directions of different technological fields

\begin{tabular}{|c|c|c|c|c|c|c|c|c|}
\hline & (1) & (2) & (3) & (4) & (5) & (6) & (7) & (8) \\
\hline & Intra & Inter-GET & Inter-FF & External & Intra & Inter-GET & Inter-FF & External \\
\hline \multicolumn{9}{|l|}{ Solar energy } \\
\hline Wind energy & $\begin{array}{c}-1.066^{* * * *} \\
(0.058)\end{array}$ & $\begin{array}{r}0.152^{* * * *} \\
(0.024)\end{array}$ & $\begin{array}{r}-0.134 \\
(0.080)\end{array}$ & $\begin{array}{c}-0.113^{* * *} \\
(0.026)\end{array}$ & $\begin{array}{c}-1.044^{* * * *} \\
(0.058)\end{array}$ & $\begin{array}{r}0.171^{* * * *} \\
(0.025)\end{array}$ & $\begin{array}{c}-0.111 \\
(0.080)\end{array}$ & $\begin{array}{c}-0.099^{* * * *} \\
(0.027)\end{array}$ \\
\hline Ocean energy & $0.161(0.303)$ & $\begin{array}{r}0.758^{* * * *} \\
(0.192)\end{array}$ & $0.971^{*}(0.445)$ & $0.030(0.231)$ & $0.184(0.307)$ & $\begin{array}{r}0.767^{* * * *} \\
(0.191)\end{array}$ & $1.020^{*}(0.452)$ & $0.038(0.230)$ \\
\hline Bio-fuels & $\begin{array}{c}-2.357^{* * *} \\
(0.080)\end{array}$ & $\begin{array}{r}0.399^{* * *} \\
\quad(0.017)\end{array}$ & $\begin{array}{r}0.312^{* * *} \\
(0.047)\end{array}$ & $\begin{array}{r}-0.000 \\
(0.018)\end{array}$ & $\begin{array}{c}-2.342^{* * *} \\
(0.081)\end{array}$ & $\begin{array}{l}0.410^{* * *} \\
\quad(0.017)\end{array}$ & $\begin{array}{r}0.339^{* * *} \\
(0.048)\end{array}$ & $0.002(0.019)$ \\
\hline $\begin{array}{l}\text { Geothermal } \\
\text { energy }\end{array}$ & $\begin{array}{c}-1.078^{* * *} \\
(0.062)\end{array}$ & $\begin{array}{l}0.295^{* * *} \\
(0.024)\end{array}$ & $\begin{array}{c}-0.370^{* * * *} \\
(0.084)\end{array}$ & $\begin{array}{c}-0.076^{* *} \\
(0.026)\end{array}$ & $\begin{array}{c}-1.048^{* * *} \\
(0.063)\end{array}$ & $\begin{array}{c}0.318^{* * *} \\
(0.025)\end{array}$ & $\begin{array}{c}-0.336^{* * *} \\
(0.084)\end{array}$ & $\begin{array}{r}-0.059^{*} \\
(0.027)\end{array}$ \\
\hline Hydro energy & $\begin{array}{c}-0.732^{* * *} \\
(0.051)\end{array}$ & $\begin{array}{c}0.106^{* * *} \\
(0.028)\end{array}$ & $\begin{array}{r}-0.148 \\
(0.090)\end{array}$ & $\begin{array}{c}-0.153^{* * *} \\
(0.031)\end{array}$ & $\begin{array}{c}-0.669^{\text {**** }} \\
(0.052)\end{array}$ & $\begin{array}{r}0.140^{* * * *} \\
(0.028)\end{array}$ & $\begin{array}{c}-0.091 \\
(0.090)\end{array}$ & $\begin{array}{c}-0.132^{* * *} \\
(0.031)\end{array}$ \\
\hline $\begin{array}{r}\text { Waste to } \\
\text { energy }\end{array}$ & $\begin{array}{c}-0.448^{* * *} \\
(0.028)\end{array}$ & $\begin{array}{c}0.159^{* * *} \\
(0.018)\end{array}$ & $0.065(0.053)$ & $\begin{array}{r}-0.026 \\
(0.018)\end{array}$ & $\begin{array}{c}-0.432^{* * *} \\
(0.028)\end{array}$ & $\begin{array}{r}0.167^{* * *} \\
(0.018)\end{array}$ & $0.079(0.053)$ & $\begin{array}{r}-0.022 \\
(0.018)\end{array}$ \\
\hline \multirow[t]{2}{*}{ Other } & $-0.938^{* * *}$ & $0.292^{* * * *}$ & $0.124^{*}$ & 0.008 & $-0.940^{* * *}$ & $0.293^{* * *}$ & $0.123^{*}$ & 0.007 \\
\hline & $(0.042)$ & $(0.021)$ & $(0.059)$ & $(0.021)$ & $(0.042)$ & $(0.021)$ & $(0.059)$ & $(0.021)$ \\
\hline BackCite & & & & & $0.009^{*}(0.004)$ & $\begin{array}{l}0.005^{* *} \\
(0.002)\end{array}$ & $\begin{array}{r}-0.007 \\
(0.005)\end{array}$ & $0.004^{*}(0.002)$ \\
\hline $\begin{array}{c}\text { Non_pat- } \\
\text { entCite }\end{array}$ & & & & & $\begin{array}{c}-0.002 \\
(0.011)\end{array}$ & $0.003(0.006)$ & $\begin{array}{c}-0.028 \\
(0.017)\end{array}$ & $0.007(0.006)$ \\
\hline IPC & & & & & $\begin{array}{r}0.034^{* * * *} \\
\quad(0.005)\end{array}$ & $\begin{array}{c}0.021^{* * * *} \\
(0.003)\end{array}$ & $\begin{array}{c}0.030^{* * * *} \\
(0.007)\end{array}$ & $\begin{array}{l}0.010^{* * * *} \\
\quad(0.002)\end{array}$ \\
\hline Inventor & & & & & $0.003(0.004)$ & $\begin{array}{l}0.006^{* *} \\
(0.002)\end{array}$ & $0.003(0.007)$ & $0.006^{*}(0.002)$ \\
\hline Applicant & & & & & $\begin{array}{c}-0.040 \\
(0.030)\end{array}$ & $\begin{array}{r}-0.007 \\
(0.014)\end{array}$ & $0.077(0.040)$ & $\begin{array}{c}-0.012 \\
(0.015)\end{array}$ \\
\hline Claim & & & & & $\begin{array}{r}0.008^{* * *} \\
(0.002)\end{array}$ & $\begin{array}{r}0.004^{* * * *} \\
(0.001)\end{array}$ & $\begin{array}{r}0.010^{* * * *} \\
(0.003)\end{array}$ & $\begin{array}{c}0.004^{* * *} \\
(0.001)\end{array}$ \\
\hline $\begin{array}{l}\text { Exptended- } \\
\text { Family }\end{array}$ & & & & & $\begin{array}{c}-0.005^{* *} \\
(0.002)\end{array}$ & $\begin{array}{c}-0.004^{* * *} \\
(0.001)\end{array}$ & $\begin{array}{r}-0.002 \\
(0.002)\end{array}$ & $\begin{array}{r}-0.002 \\
(0.001)\end{array}$ \\
\hline Constant & $\begin{array}{c}-0.123^{* * *} \\
(0.014)\end{array}$ & $\begin{array}{l}0.675^{* * *} \\
\quad(0.012)\end{array}$ & $\begin{array}{c}-1.521^{* * *} \\
(0.033)\end{array}$ & $\begin{array}{c}0.178^{* * *} \\
(0.011)\end{array}$ & $\begin{array}{c}-0.289^{* * *} \\
(0.044)\end{array}$ & $\begin{array}{r}0.544^{* * *} \\
(0.023)\end{array}$ & $\begin{array}{c}-1.769^{* * *} \\
(0.063)\end{array}$ & $\begin{array}{r}0.083^{* * *} \\
(0.023)\end{array}$ \\
\hline /lnalpha & $\begin{array}{c}0.779^{* * *} \\
(0.023)\end{array}$ & $\begin{array}{c}-0.171^{* * *} \\
(0.013)\end{array}$ & $\begin{array}{r}2.175^{* * *} \\
(0.023)\end{array}$ & $\begin{array}{c}-0.512^{* * *} \\
(0.020)\end{array}$ & $\begin{array}{r}0.771^{* * *} \\
\quad(0.023)\end{array}$ & $\begin{array}{c}-0.176^{* * *} \\
(0.013)\end{array}$ & $\begin{array}{c}2.165^{* * *} \\
(0.023)\end{array}$ & $\begin{array}{c}-0.516^{* * *} \\
(0.020)\end{array}$ \\
\hline$N$ & 38,254 & 38,254 & 38,254 & 38,254 & 38,254 & 38,254 & 38,254 & 38,254 \\
\hline
\end{tabular}

Standard errors in parentheses

* $p<0.05$

${ }^{* *} p<0.01$

*** $p<0.001$

Target patents from 1985 to 2015, patent citations from 1985 to 2019

these fields depends on the progress of other green energy technologies to a larger extent. Among them, solar energy's forward and backward references to other patents are relatively huge. This may be because solar energy technologies are so far the most plentiful and well-developed.

Table 4 shows the forward-cited estimation results of each sub-field in the types of intra-technology spillovers, intergreen energy technology spillovers, inter-fossil fuel spillovers, and external technology spillovers. Only forward citations in the same technological field are considered in model 5. It can be observed that solar energy performs better than other green energy in intra-technology spillovers, except for ocean energy. There is no credible evidence that the ocean energy performs better or poorer than solar energy. Intergreen energy and inter-fossil fuel technology spillovers are considered in model 6 and model 7. In model 6, contrary to the intra-situation, solar energy generates the least spillovers. We assume prudently that solar energy brings greater benefits to the development of its own but less to others. In contrast, knowledge from other technological fields, such as ocean energy, bio-fuels, geothermal energy, and other unclassified green energy, are particularly beneficial to the 
technical progress of other green energy technologies. In model 7, patents of ocean energy and bio-fuels are more likely to be cited by fossil fuel patents than solar energy patents, which is somewhat consistent with our description above. Geothermal energy is less likely to be cited by fossil fuels. Remarkably, although we first infer waste to energy is more likely to spill over to fossil energy in Fig. 3, our hypothesis gets no credible proofs. Model 8 contains the result of external technology spillovers. Compared with solar energy patents, the likelihood of wind energy patents, geothermal energy patents, and hydro energy patents to be cited by non-energy fields are lower. And there is no evidence that patents in other green energy fields are less or more likely to spill over externally than solar energy.

\section{Discussion and conclusion}

A variety of policies were designed to stimulate the development of green energy technologies and promote the leading role of public R\&D in green energy innovation. With the promulgation of plenty of supporting policies, the number of patents granted in the field of green energy has been increasing annually, while quality and social values need further elaborate investigations. Therefore, it is inevitable for decision-makers to settle a more specific issue that how to allocate R\&D funds scientifically and efficiently for technologies with internal differences in order to avoid a waste of inclusive equalitarianism and push for targeted support. To handle this problem, we firstly investigated the quantitative performance of public R\&D in green energy technology and different technological fields. Then we presented the total knowledge spillover effects each field made to judge its technological value from a general view. Finally, we further portraited the technological flow and mutual effect among all sub-fields of green energy, which help to clarify each subfield's motive power and influences on other fields. On the basis of discerning the research status quo of public R\&D in green energy technology, this paper aims to reveal the directions and degrees of interaction with various sub-fields, identify the most valuable technology, and provide references for the precise allocation of public R\&D funds.

(1) Through the analysis of the number of green energy patents of public R\&D in China from 1985 to 2019, it is found that more than $70 \%$ of them are concentrated in the sub-fields of solar energy, bio-fuels, and waste to energy. Though the scales of technologies in hydro energy and ocean energy, considered to belong to emerging technological fields, are relatively small, the number of patents of these fields matters. To boost these minorities, the state should stick at providing positive inspirations and supports to public $R \& D$ for the accumulation of these limited but valuable technologies.

(2) More patent citations represent more knowledge spillovers, and in turn, which technological fields public $R \& D$ can have more impact on subsequent innovation can be determined. It can be compared that there is a subsequent uplift in citations for ocean energy and geothermal energy. Their higher social value leads to larger positive externalities on follow-on innovation activities. And they are in the absence of a large number of patents as cornerstone, which is a critical concern for public R\&D. In terms of the field of solar energy, waste to energy, and bio-fuels, more quality supervision should be made to find out which one occupies more than $70 \%$ of the total green energy technologies, considering the less knowledge spillovers.

(3) Several phenomena are worthy of notes when coming to the four types of knowledge spillovers. First, it is generally accepted that self-enhancement and path dependence can promote technological progress inherently. Yet there are significant differences in the spillover effects of different technological fields. Solar energy creates higher intra-technology spillovers, and the research results of waste to energy, bio-fuels, wind energy, geothermal energy, hydro energy, and other unclassified green energy have not made as substantial contributions to themselves as the solar energy. Basic research and research in cutting-edge technologies should be stepped up from the incremental innovation viewpoint. If this continues to get concerns, the green energy industry can achieve a tremendous development through a steady stream of innovative achievements obtained from lock in.

Secondly, in inter-green energy knowledge spillovers, all of the eight green energy fields have had a distinguished impact and boost on others. This enhancement needs to be retained and expanded by some feasible countermeasures. One of them is to inspire the R\&D of key common technologies that have a broad application, which underlies the fundamental technology savings pool for the green energy industry.

Finally, although the impact of different sub-fields on traditional fossil energy and non-energy technologies is not significantly different, the influence on the latter is far beyond that on the former, which should be treated dialectically. On the one hand, green energy technologies are less integrated with traditional energy technologies. It seems that green energy and traditional energy are completely independent of each other. As a matter of fact, the combination of green energy and traditional energy has its application value. For instance, recycling and utilizing waste heat energy after traditional fuel combustion to generate power is of ecological 
and practical significance. On the other hand, it is unidentifiable to measure the explicit externality of green energy technology to non-energy technology, but fortunately we are aware of the existence of it. In terms of the development of green energy technology itself, it is far more than advantageous to create knowledge spillovers for non-energy technology. It is where the foundation and superiority of public $\mathrm{R} \& \mathrm{D}$ lies.

In response to the analysis and summary mentioned above, we propose several policies and managerial implications:

(1) The allocation mechanism of public R\&D funds is demanding for efficiency improvement when concerning about the overall differences in the amounts of technologies in different green energy fields. The method of resource allocation should be improved, and the government's decision-making orientation should be optimized so that $R \& D$ resources would flow to the technological fields where resources are most scarce. Giving priority to developing emerging technology fields under institutional constraints, trying to encourage public R\&D to overcome difficulties and foster strengths and avoid weaknesses ought to be the focus of the next green energy subsidy policy reform, Resource misallocation should be reduced, and precise support policies should be implemented. Specifically, support for solar energy should be gradually reduced to capitalize on the advantages of the market, instead support for ocean energy, hydro energy, geothermal energy, etc. should be enhanced.

(2) The concept of "high-quality innovation can drive highquality development" should be cemented, and the core status of quality should be fully implemented in the terms of policy formulation and public fund allocation. In view of the existing policies for the support of green energy innovation, especially inclusive policies, it is imperative to increase the incentives for advancing the quality of technological innovation and conduct an indepth dynamic analysis of innovation performances of public R\&D in different fields. While adhering to the dual role of policies and market to promote the development of waste-to-energy, heed should be shifted to technical fields with promisingly high quality but currently limited quantity (e.g., ocean energy and biofuels). In doing so, formulating corresponding innovation incentive policies for different technologies and increasing the weight of technological innovation quality would be possible. Thus, a comprehensive evaluation and assessment system with quality indicators as the main and quantitative indicators as a supplement can be conceivably constructed and eventually put the measures adapting to local conditions and technological conditions into effect.

(3) The top priority to evaluate green energy technology of public R\&D is to identify its scientific and social value. Therefore, the combination of innovation quality and social contribution entails emphasis of its effect to the subsequent innovation. Given inadequacy of intra-technology spillovers, it requires the government to take the lead in providing the basic research platform of green energy and excavating the true strength of public R\&D to make a breakthrough in bottlenecks to provide technological drives for the future green energy industry. At the same time, it also needs to strengthen the mutual application among different green energy fields. Since public R\&D often prefers to certain aspects, industryuniversity-research cooperation may be given a higher profile by the government to make public research promote the balance and meet the needs of industrial development of green energy. Some instrumental tactics, such as cutting-edge technology exhibitions and study tours, will also facilitate cross-border learning on the knowledge-receiving side.

There are limitations in this study and should be acknowledged. First of all, there are various innovation forms of green energy technologies for public R\&D, with patents being an important and presentative but not the only one. Other measurement indicators such as scientific paper can be added in subsequent research. Secondly, we did not make a horizontal comparison among public R\&D and other R\&D subjects, through which the differences of research subjects can be found and the roles of different R\&D subjects can be clarified further. Finally, the research object of this article is China's public R\&D (representing by governmental R\&D institutions and universities). The results may show quite different characteristics if apply our research to other developed countries. Whether or not our results can be extended to other countries depends on the further collection of data. In addition to handling these limitations, we need to pay attention to the commercialization in the field of green energy technology of public R\&D in the future. The transformation of scientific and technological green energy achievements in the public sectors is the key to achieving a circular economy and a sustainable society. Sometimes, ways to measure the social value of innovations of public R\&D may be diverse. In the future, multiple perspectives on their measurement can be considered to extend the work of this paper.

Author contribution All authors contributed to the study conception and design. Material preparation, data collection, and analysis were performed by Hong Gong, Xiuping Lai, Junlin Jiang, and Shan Dong. 
The first draft of the manuscript was written by Libing Nie, and all authors commented on previous versions of the manuscript. All authors read and approved the final manuscript.

Funding This research is supported by the National Social Science Fund of China (21BGL266).

Data availability The datasets used and/or analyzed during the current study are available from the corresponding author on reasonable request.

\section{Declarations}

Ethics approval Ethical approval was not required for this research.

Consent to participate Not applicable.

Consent for publication Not applicable.

Competing interests The authors declare no competing interests.

\section{References}

Aldieri L, Bruno B, Senatore L, Vinci CP (2020) The future of pharmaceuticals industry within the triad: the role of knowledge spillovers in innovation process. Futures 122:9

Ardito L, Petruzzelli AM, Albino V (2016) Investigating the antecedents of general purpose technologies: a patent perspective in the green energy field. J Eng Technol Manag 39:81-100

Audretsch DB, Link AN (2019) Entrepreneurship and knowledge spillovers from the public sector. Int Entrep Manag J 15:195-208

Barbieri N, Marzucchi A, Rizzo U (2020) Knowledge sources and impacts on subsequent inventions: Do green technologies differ from non-green ones? Res Policy 49(2)

Battke B, Schmidt TS, Stollenwerk S, Hoffmann VH (2016) Internal or external spillovers-which kind of knowledge is more likely to flow within or across technologies. Res Policy 45:27-41

Ben Arfi W, Hikkerova L, Sahut JM (2018) External knowledge sources, green innovation and performance. Technol Forecast Soc Chang 129:210-220

Braun FG, Schmidt-Ehmcke J, Zloczysti P (2010) Innovative activity in wind and solar technology: empirical evidence on knowledge spillovers using patent data. Cepr Discuss Pap 3:25-35

Burmaoglu S, Sartenaer O, Porter A, Li M (2019) Analysing the theoretical roots of technology emergence: an evolutionary perspective. Scientometrics 119:97-118

Caniels MCJ, Verspagen B (2001) Barriers to knowledge spillovers and regional convergence in an evolutionary model. J Evol Econ 11:307-329

Chan L, Daim T (2012) Exploring the impact of technology foresight studies on innovation: case of Bric countries. Futures 44:618-630

Chan L, Daim T (2018) A research and development decision model for pharmaceutical industry: case of China. R D Manag 48:223-242

Chen J-R, Kan K, Tung IH (2016) Scientific linkages and firm productivity: panel data evidence from Taiwanese electronics firms. Res Policy 45:1449-1459

Cohen WM, Levinthal DA (1990) Absorptive-capacity - a new perspective on learning and innovation. Adm Sci Q 35:128-152

Colombelli A, Quatraro F (2019) Green start-ups and local knowledge spillovers from clean and dirty technologies. Small Bus Econ $52: 773-792$
Costantini V, Crespi F, Curci Y (2015) A keyword selection method for mapping technological knowledge in specific sectors through patent data: the case of biofuels sector. Econ Innov New Technol 24:282-308

Dechezleprêtre A, Martin R, Mohnen M (2014) Knowledge spillovers from clean and dirty technologies. CEP Discussion Papers

Dosi G (1982) Technological paradigms and technological trajectories - a suggested interpretation of the determinants and directions of technical change. Res Policy 11:147-162

Drivas K, Economidou C (2015) Is geographic nearness important for trading ideas? Evidence from the us. J Technol Transfer 40:629-662

Feng T, Du H, Lin Z, Zuo J (2020) Spatial spillover effects of environmental regulations on air pollution: evidence from urban agglomerations in China. J Environ Manag 272:110998-110998

Florida R (1996) Lean and green: the move to environmentally conscious manufacturing. Calif Manag Rev 39:80-000

Ghisetti C, Marzucchi A, Montresor S (2015) The open eco-innovation mode. an empirical investigation of eleven European countries. Res Policy 44:1080-1093

Gkypali A, Filiou D, Tsekouras K (2017) R\&D collaborations: is diversity enhancing innovation performance? Technol Forecast Soc Chang 118:143-152

Griliches Z (1979) Issues in assessing the contribution of research and development to productivity growth. Bell J Econ 10:92-116

Grossman GM, Helpman E (1991) Trade, knowledge spillovers, and growth. Eur Econ Rev 35:517-526

Hardin JW, Hilbe JM (2014) Regression models for count data based on the negative binomial(P) distribution. Stata J 14:280-291

Hillman AJ, Dalziel T (2003) Boards of directors and firm performance: integrating agency and resource dependence perspectives. Acad Manag Rev 28:383-396

Jaffe AB, De Rassenfosse G (2017) Patent citation data in social science research: overview and best practices. J Assoc Inf Sci Technol 68:1360-1374

Jaffe AB, Newell RG, Stavins RN (2005) A tale of two market failures: technology and environmental policy. Ecol Econ 54:164-174

Kaplan S, Vakili K (2015) The double-edged sword of recombination in breakthrough innovation. Strateg Manag J 36:1435-1457

Koch L, Simmler M (2020) How important are local knowledge spillovers of public R\&D and what drives them? Res Policy 49(7)

Lanjouw JO, Schankeman M (2004) Patent quality and research productivity: measuring innovation with multiple indicators. Econ J 114:441-465

Marin G (2014) Do eco-innovations harm productivity growth through crowding out? Results of an extended CDM model for Italy. Res Policy 43:301-317

Reitzig M (2004) Improving patent valuations for management purposes - validating new indicators by analyzing application rationales. Res Policy 33(6-7):939-957

MesseniPetruzzelli A, Murgia G (2020) University-industry collaborations and international knowledge spillovers: a joint-patent investigation. J Technol Transfer 45:958-983

Mowery DC, Nelson RR, Martin BR (2010) Technology policy and global warming: why new policy models are needed (or why putting new wine in old bottles won't work). Res Policy 39:1011-1023

Narin F, Hamilton KS, Olivastro D (1997) The increasing linkage between U.S. technology and public science. Res Policy 26:317-330

Nemet GF (2012) Inter-technology knowledge spillovers for energy technologies. Energy Econ 34:1259-1270

Nemet GF, Johnson E (2012) Do important inventions benefit from knowledge originating in other technological domains? Res Policy 41:190-200 
Noailly J, Smeets R (2015) Directing technical change from fossil-fuel to renewable energy innovation: an application using firm-level patent data. J Environ Econ Manag 72:15-37

Novelli E (2015) An examination of the antecedents and implications of patent scope. Res Policy 44:493-507

Oltra V, Jean MS (2005) The dynamics of environmental innovations: three stylised trajectories of clean technology. Econ Innov New Technol 14:189-212

Pearson PJG, Foxon TJ (2012) A low carbon industrial revolution? Insights and challenges from past technological and economic transformations. Energy Policy 50:117-127

Pfeffer J (1972) Size and composition of corporate boards of directors - organization and its environment. Adm Sci Q 17:218-228

Plank J, Doblinger C (2018) The firm-level innovation impact of public R\&D funding: evidence from the German renewable energy sector. Energy Policy 113:430-438

Popp D (2019) Environmental policy and innovation: a decade of research. Int Rev Environ Resour Econ 13:265-337

Popp D, Newell R (2012) Where does energy R\&D come from? Examining crowding out from energy R\&D. Energy Econ 34:980-991

Rennings K, Rammer C (2011) The impact of regulation-driven environmental innovation on innovation success and firm performance. Ind Innov 18:255-283

Roach M, Cohen WM (2013) Lens or prism? Patent citations as a measure of knowledge flows from public research. Manag Sci 59:504-525

Schilling MA, Green E (2011) Recombinant search and breakthrough idea generation: an analysis of high impact papers in the social sciences. Res Policy 40:1321-1331
Schoenmakers W, Duysters G (2010) The technological origins of radical inventions. Res Policy 39:1051-1059

Singh J (2008) Distributed R\&D, cross-regional knowledge integration and quality of innovative output. Res Policy 37(1):77-96

Stephan A, Bening CR, Schmidt TS, Schwarz M, Hoffmann VH (2019) The role of inter-sectoral knowledge spillovers in technological innovations: the case of lithium-ion batteries. Technol Forecast Soc Change 148

Todo Y, Matous P, Inoue H (2016) The strength of long ties and the weakness of strong ties: knowledge diffusion through supply chain networks. Res Policy 45:1890-1906

Van Den Bergh JCJM (2008) Optimal diversity: increasing returns versus recombinant innovation. J Econ Behav Organ 68:565-580

Vuong QH (1989) Likelihood ratio tests for model selection and nonnested hypotheses. Econometrica 57:307-333

Xu X, Yuan W, Meng S (2010) Generalization of negative binomial regression model and its application to classification ratemaking. Appl Stat Manag 29:656-661

Zhao SL, Jiang YH, Wang SY (2019) Innovation stages, knowledge spillover, and green economy development: moderating role of absorptive capacity and environmental regulation. Environ Sci Pollut Res 26:25312-25325

Publisher's note Springer Nature remains neutral with regard to jurisdictional claims in published maps and institutional affiliations. 